\title{
Awramba Community: The Unique Cultural Practices as a Center of Cultural Tourism
}

\author{
Getinet Merid Ekimie \\ Lecturer, Department of History and Heritage Management, University of Gondar.P.O.Box, 196
}

\begin{abstract}
In the paper, it has been tried to explore the aspects of unique cultural practices of Awramba Community, attitudes of the surrounding society and to show what the community experienced and the challenge that community faces to survive and thrive. In order to achieve the objective, the research has used qualitative research method. Primary and secondary sources have been collected through key informant interview, Focus Group Discussion (FGD) observation and document analysis. Extensive oral tradition and oral information were also substantiated in the study.Awramba is a community guided by its own unique principles, namely, respecting women's rights to equality, respecting children's rights; helping people who are unable to work due to physical limitations; avoiding negative speeches and deeds while promoting cooperation, peace, good deeds and accepting all human beings as brothers and sisters. The community has unique characteristics that make them different from the surrounding society. This society's social fabric promotes strict work ethics, gender equality, division of labor, marriage and divorce based on free will, old age protection, social solidarity, less ceremonial funeral, and managed internal conflicts and others. There are two types of membership in Awramba community. These are the member of the association or union known in Amharic as Yemaheber Abal and full honorary membership, in Amharic Yemahberesebu Abal. Their culture is practice-oriented. It has been described by some members of the community as a movement which aims not mainly to convince, but to act, and build a new society. So, this study is to be sought in the considerations of the filling of the gaps and earnestly aimed to benefit readers and researchers about the indigenous cultural practices of the community.
\end{abstract}

Keywords: Awramba, Community, Cultural Practices and Cultural Tourism

DOI: $10.7176 /$ JTHS/53-03

Publication date: January $31^{\text {st }} 2021$

\section{INTRODUCTION}

Ethiopia is home to more than 80 nations and nationalities with distinct cultural and linguistic characteristics. The country has unique culture and religious composition; it is a mosaic of the continent and a museum of modes of productions. Besides 'traditional' religions, its inhabitants practice major monotheistic religions like Christianity and Islam. In religion section developed with the involvement of local experts will provide enough information about the country's religious practices which are completely unique from the rest of the world (Bahru, 1991, p.7). These people have practiced different religious, developed distinct social and cultural identities which have been transmitted over many generations. These cultural, social and religious practices have been sources of tourist attractions along with the natural endowment and historical attractions of the state. Among these the Awramba community is one of the communities that has unique cultural aspects (Getinet, 2014, p.1).

The Awramba community is situated in a small rural village in South Gondar Zone, Fogära wereda, in one of Wäji-Arba-Amba, sometimes called Wäjina-Arvamba Kebele at avillage known as Ţuräňe in Amhara National Regional State. The community is found $635 \mathrm{~km}$ from Addis Ababa, $68 \mathrm{~km}$ from Bahir Dar, $32 \mathrm{~km}$ from Däbrä Tabor (the capital of South Gondar Zone) and $12 \mathrm{~km}$ from Wäräta, on Wäräta-Wäldiya main road. The Awramba community is situated between $11^{0} 56^{\prime}$ '07' North latitudes and $11^{0} 55^{\prime} 25^{\prime \prime}$ East longitudes (Getinet, 2014, p.8; Getu, 2010, p.15).

The foundation of Awramba community can be traced back to1972 when the community was established. The community was established by philosophy of one visionary man called Zumra Nuru Muhammad. According to many sources he has unique vision and exceptional personality. He shared his five basic principles with the community as to how to put these principles in-to practice in a way that would be relevant for their lives. The principles are: respecting the right to the equality of women, respecting children's rights, helping people who are unable to work due to old age and health problems like, avoiding bad speech and bad deeds, such as theft, dishonest, insulting, cursing, quarrelling, killing, conflict, etc, instead improving practices of cooperation, peace, love, and good deeds in general and accepting all human beings as brothers and sisters, regardless of their differences. The community organized as "the Awramba Community Farmers' and Handicraft Multipurpose Cooperative" in 1986 by 19 members. Later, this organized farmers' cooperation of Awramba village or union was regularly threatened and segregated by the neighboring societies. The neighboring society accused the members of the community of being supporters of the Ethiopian People Revolutionary Party (EPRP), which was anti-Derg at the time. Hence, the Derg interrupted the creation of the association and Zumra was thrown in jail in 1985. In the final days of the Derg regime in 1986, Zumra was released from jail after he stayed for six months. In 1988 Zumra and his followers 
moved to Southern part of Ethiopia particularly, Kafa Zone, Ginbo wereda, at Mädefäňn̆a Kebele, to save their life (Getinet, 2014, p.13).

After the dawn fall of the Derg government in 1991, the members of Awramba community decided to return and came back to their former area, in Awramba and the community was again reestablished in 1993 on its present area and began to expand afterwards. The Awramba community has their unique features of social structure. The community has their own system of commonality, social organization, administration system, traditional conflict management system, economic activities and other social relationships. The community of Awramba shares a strong culture and ideals with each other, which differentiate them from the Amhara society and their neighboring villages, and above all they shared common values. Among those unique characteristics that make them different from the surrounding society, and also most part of Ethiopia, are their work ethics, equality especially gender equality, division of labor, religion, marriage and divorce, old age protection, solidarity, funeral, house building design /style/, management of internal conflicts and others are the major one. Such unique cultural practices are as a means for tourism attractions (Getinet, 2014, p.29). Therefore, this study is to be sought in the considerations of the filling of the gaps and seriously aimed to benefit readers and researchers about the unique cultural practices of the community.

\section{Unique Cultural Practices of Awramba Community}

Any society has a system of values, a set of ideas, concepts and behaviors in relation to which it is strongly committed. The term of culture refers rather to a set of knowledge allowing individuals and groups to assert and interpret the values, beliefs, customs and behaviors, which distinguish them from other groups or societies. The values or the culture of a society are never unchanging, but evolve over generations, especially to adapt to a new environment (Said, 2008, p. 78). The community of Awramba shares a strong culture and ideals with each other, which differentiate them from the Amhara society and their neighboring villages, and above all they shared common values. To live in Awramba means to share and to defend their values. Among those unique characteristics that make them different from the surrounding society, and also most part of Ethiopia, are their work ethics, equality especially gender equality, division of labor, religion, marriage and divorce, old age protection, solidarity, funeral, house building design /style/, management of internal conflicts and others (Informants: Enanäy, Beretukan, Ťähayi and Dämäqä).

\section{The Work Ethics of Awramba Community}

The work ethics of the Awramba community can be assessed based on how they feel about their job and how they share the responsibility of their task that they perform.

Members of the community have a good work ethics, mainly their value and attitude for work, their internal motive for hard work and proper time management as well as honesty and accountability (Fogära District Office, 2001 E.C., p. 10).

They use all every day in a week properly for different activities. The community has no any holiday ceremony to celebrate. The only holiday in the village happens on the first day of the New Year, September, 1, in Ethiopia calendar (1 $1^{\text {th }}$ of September) (Dereje, 2013, p. 25).

Except the New Year, members are engaged in work every day and do not observe any other public or religious holiday. Except governmental employees, all members of the cooperative spend five days a week doing communal work, with nine hours a day, till 5 PM. The community members spend one day among the 5 communal days in a week for helping the elderly, the ill and the needy and for maintenance. This day is Tuesday, referred to as a "progress day".

Everyone is free to work for themselves outside these working hours. The villagers can spend the seventh day of the week as they give pleasure to. Usually they go to market, wash and clean, or collect wood. This day off is Wednesday in the first week and Saturday in the next week, i.e. four days per month. The Awramba inhabitants work a lot for work constitutes an essential value in the community (Amsalu, 2009, p. 30; Informants: Zumra, Enanäy Beretukan, Ťähayi and Dämäqä).

Awramba leaves little room for free time and enjoyment. Life is a serious thing to be wasted on luxury or on pursuit of personal satisfaction. There is little room for gambling or dancing, neither for sex outside marriage. There is no coffee ceremony as it is regarded as a waste of time and a stage for bad-mouthing, while this rather long ceremony is important in Ethiopia, whose national drink it is. It is for the foreigner, especially, a great experience of affective pleasure (Abebew, 2007, p. 52; Informants: Zumra, Enanäy and Beretukan). 
Table: 1. List of Activities Performed on weekly basis

\begin{tabular}{|l|l|l|}
\hline Day & \multicolumn{1}{|c|}{ Activity } & \multicolumn{1}{c|}{ Purpose of the activity } \\
\hline Monday & Communal work & Communal purpose \\
\hline Tuesday & Communal work & To help others who cannot support themselves \\
\hline Wednesday & Communal work & Communal purpose \\
\hline Thursday & Personal work & personal purpose \\
\hline Friday & Communal work & communal purpose \\
\hline Saturday & Personal work & personal purpose \\
\hline Sunday & Communal work & communal purpose \\
\hline
\end{tabular}

Source: The Awramba Community Information Center, 2013

The Awramba community works hard without gender discrimination and shares the profits they earn at the end of the year. This is one of the unique characteristics, which makes it very different from the rest of the society. In the community females have equal right with male to participate in any activity and to share benefits equally. In the time of pregnancy women's get rest time 1 month before birth and 2 months after birth. After this she returns to her former work (Debub Gondar Zone Office, 2001 E.C., p. 45; Informants: Enanäy, Beretukan, Ťähayi and Dämäqä).

\section{Equality in Awramba}

In Ethiopia, in the past, many groups like smiths, tanners, potters, woodworkers or weavers have been despised and ostracized, being denied access to land and livestock and restricted to their craft activities. At the same time, in some cases they are feared and considered to have links with evil forces, especially the smiths. They can therefore be considered to have a dual status: Such like socially and economically oppressed (Said, 2008, p. 26). It is important to remember that the traditional Ethiopian society tends to isolate a given groups, which are not well considered, not according to their behavior or their personal value, but according to their occupation. On the contrary, an essential value of Awramba is equality, which obligates respect differences in religion, color, race, ethnic group, job specification, physical or intellectual capacity, etc. The usual hierarchical system, which often leads to a competition to move up the social ladder, is replaced by social equality through social cooperation and gender equality (Solomon, 2005, p. 49; Said, 2008, p. 73).

There is no division the community members into those who command and those who obey, since the social recognition is not linked to the social position or to the job, but to the daily respect of the community values. Then, in order to prevent any attempt by someone to seize power, all committees' positions should be held for a maximum of 2 to 3 years (Solomon, 2005, p. 56. Informants: Enanäy, Beretukan, Ťähayi and Dämäqä).

The value of Awramba about equality, humanity and brotherhood is extended to universal brotherhood. Black and white, all are equal by nature. When Zumra is asked about ethnic relationship, he simply says, "we belong to every ethnic group, not one or the other". For this reason, foreign visitors pay the same rates as their Ethiopian counterparts, which are rarely the case in Ethiopia (Informants: Zumra, Beretukan and Tähayi). The community claimed equality not only between men and women, but also between adults and children, and more generally between human beings. Many literatures uphold that sex difference is biological and physical, while gender inequalities are socially constructed that transfer throughout many generations. The latter is social or cultural interpretations of sex differences, the roles assigned to or expected from each sex in a specific society.

In Ethiopia, even the roles assigned to each sex vary from one region to the other. Girls are educated during their childhood to be compliant and withdrawn. Women suffer from socio-cultural and economic discrimination and have fewer opportunities compared to men for personal growth, education and employment opportunity (Abebew, 2007, p. 58; Informants: Enanäy, Beretukan, Ťähayi and Dämäqä).

Gender is the main factor concerning work. For instance, baking injera and fetching water is left only to females; plowing, hunting, slaughtering are works left only to males. Women and the youngest do most of the work. Among Amhara peasants, the wife is too busy in the morning to sit down for a regular breakfast; she has breakfast while doing her various works: preparing and baking injera, preparing the local beer (täla, aräqé), spinning cotton, collecting dung for fuel, comprehensive, garbage of the floor, carrying water from the spring, weaving straw baskets of mats. If the peasant is working in a distant farm field, his wife carries lunch out to him. Otherwise, she risks being beaten with a stick. If he is not far away, he comes to lunch, they eat together at home. After dinner, the peasants ask often his wife or his children to wash his feet (Ibid).

In many parts of Ethiopia, husbands were still authorized to order their wives. The woman's plan is today only lightened, not completely removed. Except for a possible journey to church with her husband on Sunday morning before breakfast, females are still confined to home compounds and they have many responsibilities. In wealthier families, where one or several servants are in charge of the hardest works, woman must still be passive and reserved. Women are beaten as a matter of cause for mistakes in their work. The status women enjoyed in traditional Amhara society is therefore to be at home and her main work is to serve her husband and her children (Solomon, 2005, pp. 45-46, Abebew, 2007, p. 58; Informants: Beretukan and Gäbäyähu Däsalän̆). 
Culture and tradition determine who is involved in what activities and exempt others from taking responsibility in certain areas. A lot of these practices have been passed from generations to generations. This gender division of labor is one of the major barriers to women's participation and their empowerment. On the contrary, Awramba considers work as a moral value, even the most important one, "the essence of life" as said by a community member. Work is an answer to poverty, but it is first of all a means of accomplishment and to be involved in the community welfare, fundamental need rather than a means to meet ones needs. It is not absolutely compulsory and therefore alienating, but voluntary, made for its own benefit and for the community good. To work within its capacity is a moral duty. Everyone is engaged in work assigned to him or what he thinks is good for the community. The person who neglects his responsibilities or who is inefficient in his work does not get the respect by others. Absence from work, even for good cause, brings even to feeling of guilt (Ibid; Informants: Enanäy and Beretukan).

The value of any work, for all are clashing with traditional values such as division of work based on sex, patriarchal authority, subjugation of women and observance of public holydays according to religious rules, whose irrationality is so highlighted. Therefore, every adult community member must work, with exception of the infirm elderly, the ill and the women close to childbirth. All works are equally valued and no task is attributed according to sex or age considerations as such, but only according to personal capacities (Solomon, 2005, p. 50; Abebew, 2007, p. 54)

In Awramba, the division of physical work is based on one's ability. Therefore, disabled individuals and the elderly have very few labor-oriented responsibilities. Income is distributed equally among adults in the community by considering the number of children in each household. A focus group discussion of young men revealed that the baking of injära (an Ethiopian national food traditionally prepared by women), fetching water and weaving are not assigned to members of the community based on their gender. Fulfilling these duties is considered part of their responsibilities too. Interestingly, when Awramba was first show cased on a national broadcast on Ethiopian Television (ETV), Zumra himself was shown threading cotton and the other man baking injera (Ibid; Dereje Kifle, 2013, p. 52).
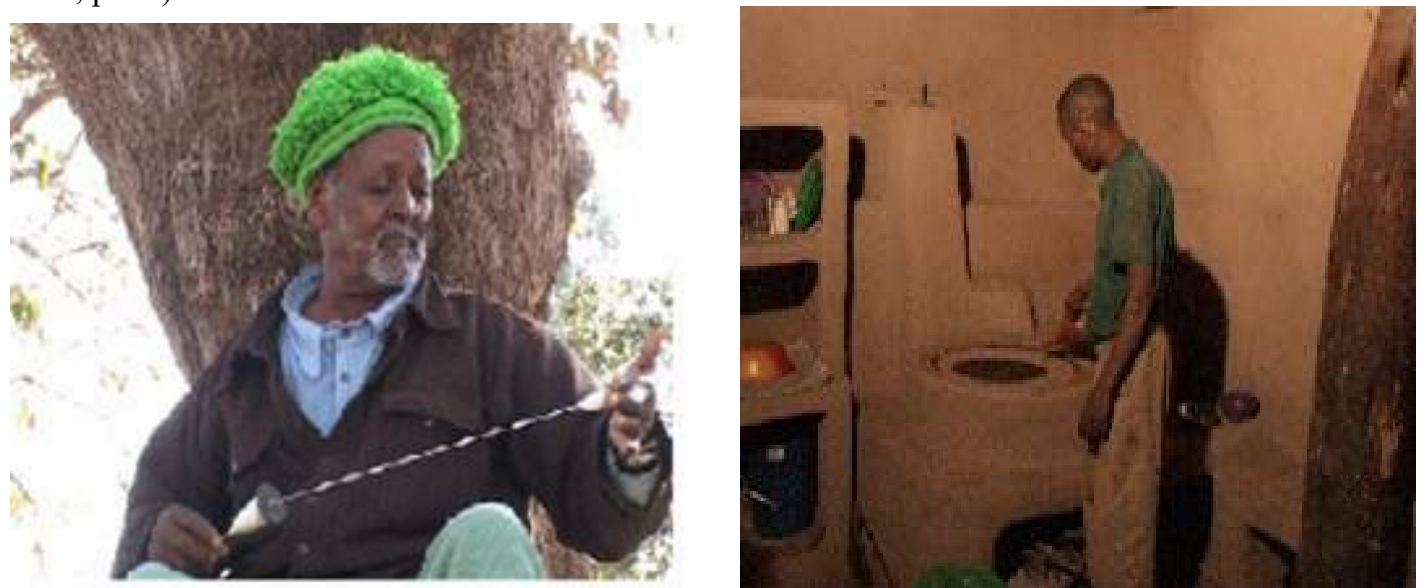

Figure: 1. Threading Cotton and Baking Injera (Zumra on the left and the other member on the right) Source: The Awramba community information center, 2018

Zumra said: "I came up with such an idea out of things that I have seen in my family. My parents were farmers. They both spent the whole day in the farm but when they came back home it was time for my father to rest but never for my mother. After she has been through the same tiresome day with my father, she had to do everything at home. She was expected to cook, clean the house, and us, the children, wash my father's foot, serve the traditional meal. On the top of that, when my mother could not take care of the house on time, my father abused, insulted and sometimes harmed her. I just wondered why this had to happen to my mother as if she had extra strength or something. But I realized later that this was not an isolated event that only happened in our house, rather it was happening in all families. At the time, I believed (as I do now) that the man as a father and the women as a mother should be engaged in duties in accordance to their capacities and should both be respected and treated equally (Ibid).

The women of the Awramba community equally participate with men in agricultural production. The women plow the land with oxen while men perform domestic activities at home like fetching water and other chores. The division of labor, in this area, is based on age rather than sex. Hence, both women and men are equally considered as producers and have equal position and value in both agricultural production and decision making (Geremew, 1994 E.C/ 2012; Informants: Zumra and Beretukan).

Members of the Awramba community view gender equality as a precondition for community development. The women can engage in cultivation, weaving and producing industrial goods and participating in different 
responsibilities. The men participate as well in fetching water, caring for children, in threading cotton and collecting firewood, activities which in most other parts of country are left up to women.

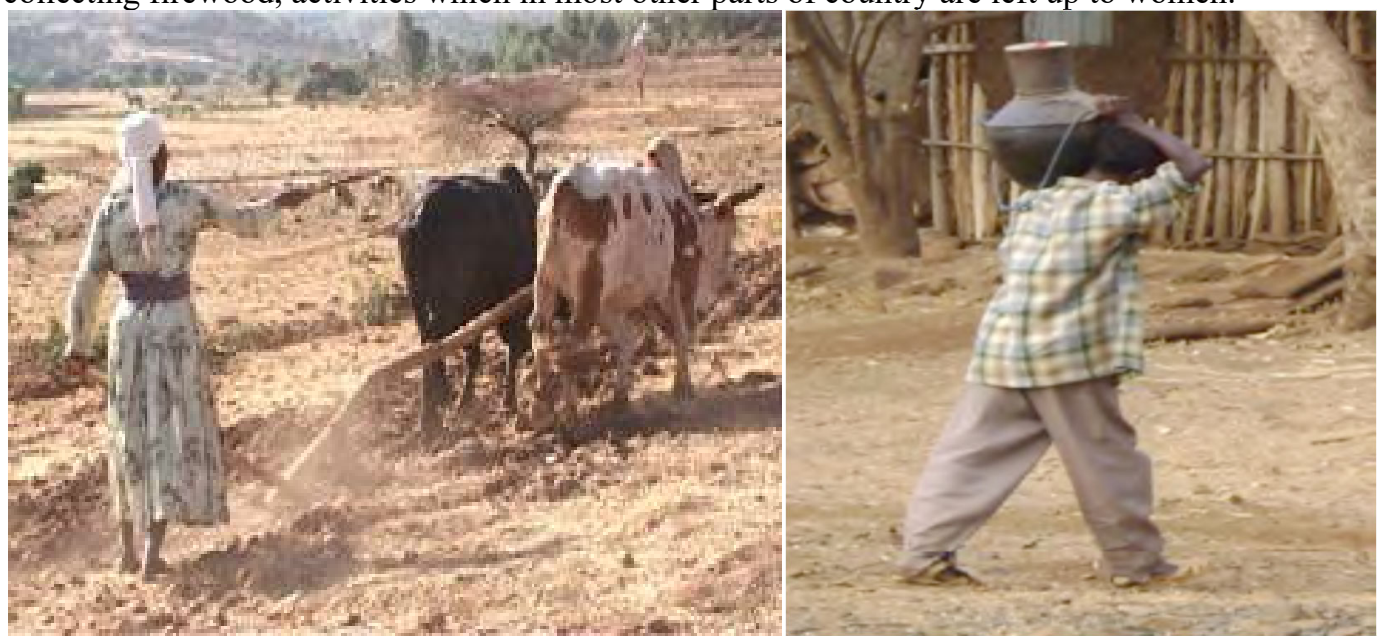

Figure: 2. Woman plowing and man fetching water

Source: The Awramba community information center, 2018

The community welcomes women who leave their offensive households and villages to seek protection in an environment that values their attitude and contributions. Ideas and practices that strengthen the notion of male superiority are impossible in the Awramba community (Mohammad, 1996, p.38; Informants: Enanäy, Beretukan, Ť̈hayi and Dämäqä).

In Awramba, woman's inferior position in the economy was abolished thereby avoiding the traditional division of work based on gender. Women contribute to their household on an equal footing with men, and fulfill their own economic needs without depending on their husband; they have full control over their income. The nongendered division of labor has a positive educational impact as children in the community grow up integrating and internalizing equality based perspective that has the ability to continue impacting neighboring communities (Said, 2008, p. 105; Dereje, 2013, p. 53; Informants: Enanäy, Beretukan and Zumra).

The community was indeed founded on the refusal of the patriarchal authority of men and the subordination of women. Activities have not to be based on sex and children are encouraged to participate in any activity, depending on their age. Work, functions and responsibilities are assigned based on ability rather than sex or gender. It is a social rule and a personal behavior. Gender division of work is therefore minimal. Both men and women share the work in the kitchen and other traditional female occupations. They both share also the outside work and more generally all traditional male occupations. Both the mother and father share equal responsibility of their family and of their young children. No one has authority over another, and economic decisions are on mutual consent. There is role reciprocity: men stay at home and women work outside, and vice-versa. Women equally participate with men in productive and reproductive works in Awramba community. Their work is equally valued as men work (Guday and Eskindir, 2013, p 160; Merhastidk, 2009, p. 29; Abebew, 2007, p. 91; Solomon, 2005 , p .78).

In Awramba there is no division of labor based on gender. Rather the community members equally participate both in productive and reproductive role based on their capacity. Accordingly, both men and women participate in collecting fire wood, cooking food, fetching water, caring for children, bringing goods to market, spinning, cotton clearing, taking care of animals, plowing etc. They argued that only pregnancy and breast-feeding are the limited domains of women, because they are linked to a physical reality and not to a social choice. Concerning to the contribution of gender equality the community got different certificates from Addis Ababa University and University of Gondar in 2001 (Eskinder, 2012, p. 54).

\section{Equality between Children and Adults}

In Amhara region children are considered inferior to adults because they are governed by ignorance and passion. After 2 or 3 years, children come to be looked on as servants, most of actions of which are ordered (Solomon, p. 46 and 91). At the age of 4 or 5, children are given simple chores, such as shooing chickens from grain drying in the sun or collecting bits of firewood. Somewhat older children are expected to protect the crops against animals and to herd cattle, till they are 12 years old. While all these childhood tasks are shared by both sexes, the Amhara girls begin to do distinctively female work at about 6 or 7 . It is also common practice that at around 10 years the Amhara girls leave the shepherd's work once and for all and spend all their time in the house. They learn gradually all the arts of the housewife. By the age of 12 or 13 they know enough to manage a home by them and are expected to be married (Ibid, p. 87). 
Since they are also forced to marry early, they become pregnant too early; they have pregnancies too close together, with not only a risk of death during delivery but also a risk of death for children. Children's rights are not respected in the Ethiopian society as they should be. Too often, children are made to do jobs that take no account of what they can really do. In Awramba community, however, the children respect their elders and the elders do the same to the children; there is no discrimination based on age, but only based on capacity. The Children in Awramba community starting from the age of three or four were given work that was beyond their capacity. Then, when the work was not done properly because of their inability to do it, they were told off (Abebew, 2007, p. 53).

Most of the informants in the community told that,

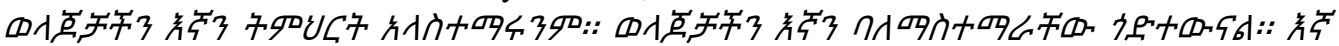

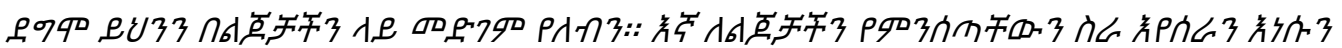

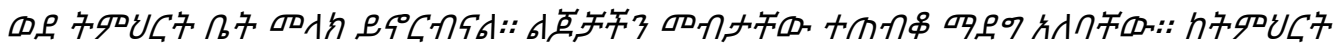

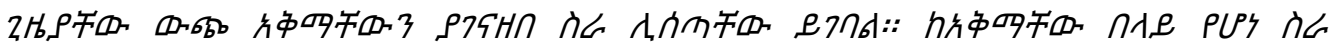

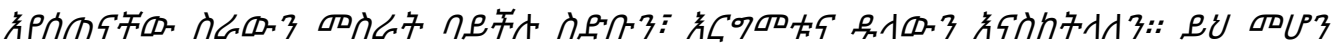

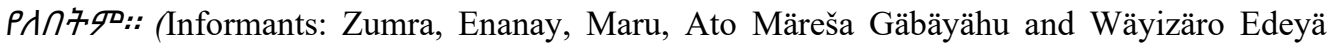
Ahmed).

"Our parents didn't give us a chance to study. This affected our lives. We shouldn't repeat this situation to our children. We, as adults, should do the work that we give to our children and we should send our children to school. Our children should grow up with their rights being respected. Once they leave school, they should be given work based on their capability. But if children are forced to work beyond their capability, that means that they are insulted, cursed at, and beaten. This shouldn't happen".

It is however important to involve children in house tasks, parallel to their academic education, starting from their childhood so that they understand what house works are. Besides the parents should allow them to distinguish between what is good and what is bad, they are advised to put into practice good things and avoid bad things. The parents shouldn't look down upon their opinions, and they should accept them as equals. If their thinking is good, they encourage them. However, if they make a mistake the parents advise them not to do it again. This is fundamental to create a high-quality generation (Informants: Zumra, Enanäy and Beretukan; Abebew, 2007, p. $53)$.

\section{Religion in Awramba}

Religion is an organized approach to human spiritual life which usually encompasses a set of narratives, symbols, beliefs and practices, often with a supernatural or transcendent quality that give meaning to the practitioner's experiences of life through reference to a higher power or truth. The term "religion" refers to both the personal practices related to communal faith and to group rituals and communication system to share confidence (Ibid; Informants: Zumra, Enanäy, Beretukan, Ťähayi and Dämäqä).

In most part of Ethiopian communities consider life as a stage that could prepare them to life after death. The real world is understood as a temporary period, where everyone suffers, by poverty and hunger are considered as hardships towards eternal life and therefore positively accepted. In a people where all these beliefs are so deeply rooted, values and attitudes have not the objective to improve the life on Earth. It leads to mortal for the life on Earth and makes improbably even the concept of development may distress (Said, 2008, pp. 26-27; Informants: Zumra, Enanay, Maru, Märeša and Ato SänäduYibré).

Members of the Awramba community don't believe in a divine power allowing and sending hardships; they only believe in the existence of one Creator, who created the sky, earth, night, day, female and male, air, sun and all the creatures that exist on earth, and their belief is expressed by good deeds. Therefore, the members of the community live by doing good deeds for others and avoiding bad deeds from being done to others. The community obeys by the generally accepted motto 'do to others as you would do to yourself' (Ibid; Abebew, 2007, p. 57; Informants: Märeša, Maru and Ato Sänädu).

All members of the community do not practice any clearly recognized religion. But they appreciate good things such as loyalty, kindness, good ethics and working disciplines, moral value, taking risks and sharing problems, equal treatment of members and fair distribution of production, maintain peace, social security and help one another (Getu, 2010, p. 18; Informants: Märeša, Maru and Zumra).

The community shows a considerable respect to teaching of Christianity as well as Islam. However, they never practice any activities that manifest religion like praying and worshiping. The leader of the community emphasizes that the community is not totally against religion, but the practice associated with religion should not be barriers to development. The community also does not observe any kind of religious practice at all. Zumra and his wife Enanäy said, "At the beginning, we were Christians or Muslims, but today, we believe in the same creator. $\mathrm{He}$ (the creator) is everywhere around us and in us. There is no need to shut him in a church or in a mosque, that 
as human beings are of one common root, or religion faith is to love, support each other and live together, avoiding all the things that cause conflict among human being and we don't believe in life after death, as we have no proof of that." (Fogera District Office, 2001 E.C., p.19; Informants: Zumra, Enanäy, Maru, Märeša and Ato Sänädu).

Therefore, the Awramba community does not follow any religion, and they believe in honesty and love for all human beings. Enanäy, the community guide, said: "We build our paradise in this life, by working and showing solidarity to others and we have no Bible, but we put into practice the main principles we found in the holy books: no theory, but practice". Zumra also expressed that: "we are practical, we need peace, and we build it. We need to help each other, we do it." But in fact, members of the community are not pure atheists, still they believe by one creator but they never give specific name like (God or Allah), because they assume that it is a cause of conflict and war in different parts of the world. The community got different awards from international organizations. For example, Zumra was awarded the honorary title of "Yäsälam Ambasadär" or "Ambassador of Peace" from United Nation (Ibid; Biniam, 2009, p. 36).

According to Zumra indicated that when the question of religion is raised, 'mankind has one root. Some say it started with Adam and Eve and other prefer to say it was Adam and Héwan, I decided then to ignore such lines, which create differences among human beings, and establish a 'heaven' that has a place for all by giving love to each other and avoid all cause of conflict and we have no time for religious dogma except work hard' (Biniam, 2009, p. 36; Informants: Zumra, Enanäy, Beretukan, Ť̈hayi, Sänädu, Dämäqä and Märeša).

\section{Marriage in Awramba}

Marriage is a social, religious, spiritual or legal union of individuals that create kinship. It is an institution in which interpersonal relationships (usually intimate and sexual) are acknowledged by the state or religious authority. People marry for many reasons, but usually one or more of the following: legal, social, emotional, and economic stability, the formation of a family unit; and born children. A marriage is often formalized by a ceremony called a wedding, which in modern times is usually performed by a religious minister of a civil officer (Said, 2008, p. 80; H. David Oslow, 2000, p. 57).

In the community, marriage shall be entered with the full consent of the couple. When two agreeable people enter into marriage, they will put down a strong foundation for the marriage. When couples are married without their consent, that forced by their parents, it will most likely lead to divorce (Ibid; Informants: Zumra, Enanäy, Beretukan, Ťähayi and Dämäqä).

In addition, such situation may also lead to abduction. In Awramba community, marriage shall be entered at the age of 19 for females and 20 for males. This ensures that the participants make the decision to marry of their own free will. Before marriage, both the woman and the man should abstain from sex. After marriage the husband shouldn't have any other sexual partner except his wife and the wife shouldn't have any other sexual partner except her husband. Marriage is a supreme (respectable) institution in the community (Ibid; Qum Nagar Magazine, 2012, p. 31).

When two couples in Awramba got married, they put their signatures on a document in the presence of eyewitnesses. Most of the time, parents have no great role, unlike the traditional Amhara societies. In the community there is no specific eyewitness for marriages or divorces. Anyone that is found in the nearby area, either male or female, can act as a witness for the marriage ceremony (Abebew, 2007, p. 48; Merhastidk, 2009 , p. 38; Said, 2008, p. 80).

Traditionally, the groom didn't even know what his bride looks like until the wedding day. This practice is still prevalent in the rural areas of the region. Parents play an important role in the choice of partner to their son or daughter and carefully inspect the families of potential partners of their child. Once the marriage is decided, the two families compete in preparing costly feasts for the occasion, in order to show their social status. The boy who dares to choose a wife on his own commits an offense for which the father has the moral right to curse and disinherit him. Marriage is regarded as a bond between families, not between individuals (Solomon, 2005, pp. 46-47).

But, in Awramba community, when a marriage takes place no one says "I am the bride and I am the bridegroom" and neither the bride nor the bridegroom stays idle. Both go to their work places afterwards to do their regular activities. In the community, married couples do not organize a wedding ceremony. The bride and bride groom will not even prepare tea. Only if guests came for the occurrence from a faraway place, the couple may prepare lunch. This is because in Awramba they believe that it is not necessary to waste their income that they have worked for during a long time. Rather, the expenses that would have gone towards a wedding ceremony can support financially the couple's lives and career. Marriage without a wedding ceremony is also necessary to avoid break away the marriage between the couples. This thinking is based on the potential situation where if parents have no money to pay for their children's' wedding and the couple who wants to marry knows that their marriage cannot happen due to shortage of money, they may decide to abandon the whole thing (Ibid, p. 41; Informants: Zumra, Tähayi, Sänädu, Enanäy and Beretukan).

The husband and the wife together decide where they are going to live. They may either move in with the woman's parents or the man's parents to begin with. All big issues will be discussed and decided upon equally 
between the couple. This way they are able to live in peace and with happiness (Ibid). Over the last many years, the taboo custom which prohibits any marriage relation till the $7^{\text {th }}$ generation in the Amhara region has been reduced to 4 or 5 generations, in order to deal with the lack of opportunities of exogamous partners. People from an outside the community are little attracted by a life in the community whose culture is very different, and the neighboring communities ban any marriage with an Awramba member. Zumra stated that "the community members can go and marry an outsider. The outsider also can come and marry a community member, but he should live our life; otherwise it is forbidden" (Ibid).

Married women have an absolute right to contraception (natural as well as artificial ones) without the knowledge of their husbands if necessary, and all are aware of contraception. Contraception is anyhow widely used in different parts of Ethiopia. The community considers that a woman older than 45 ages should no longer have children. Nevertheless, the community does not entertain the right to abortion, illegally. They think that abortion remains a private affair, always possible in a private clinic in town (Merhastidk, 2009, p. 38; Abebew, 2007, p. 79. Said, 2008, p. 77 and 82).

Rape is definitely prohibited, and a boy accused of rape can be banned from the community or have to wait for a long year to get married. The community used different control mechanism over the sexual life before marriage with a rigorous self-discipline based on the values and principles of the community (Solomon, p. 42; Informants: Zumra, Beretukan, Ť̈ähayi, Sänädu, Dämäqä and Märeša). In Awramba community, marriage is one to one and it is considered sustainable. Polygamy is absolutely forbidden in the community. This leads to respect for children and builds a strong family foundation. In order to manage the conflicts within the couples and between members of the community, several permanent bodies have been implemented. They seem very efficient to facilitate dialogue and manage conflicts in a wise manner (Ibid).

When divorce occurs, and if children go with their father, they will miss their mother, and if they go with their mother, they will miss their father. Therefore, in the community, divorce is not allowed without fundamental reasons. But if the couple faced basic problems that cannot be resolved, divorce is allowed. Problems that may lead to divorce include permanent illness, particularly which prohibits sexual intercourse; uninterrupted disagreement between the couple; infertility in one of the partners and if one of the couples abuses the regulation of the community (Awramba Mahebäräsäb, p.14; Informants: Zumra, Enanäy, Beretukan, Tähayi and Dämäqä).

In the community, the procedure for divorce is that the complaint resolving committee identifies the problem of the couple and tries to resolve it. If the problem is resolved by the Complaint Resolving Committee, their marriage shall not be interrupted. If not, the problem will be presented in a meeting with the entire community. In the meeting, the problems of the couple shall be investigated thoroughly. If the couple's problem is not one of the issues listed above, the members of the community will resolve their problem and their marriage will continue. But if their problem is about one of the issues that lead to divorce, the members of the community will decide to end the marriage. The divorced couple will share their properties including their house equally. The separation of the couple after having children causes the right of children not to be respected. Children choose to be taken care of by both parents (Solomon, 2005, p. 42).

\section{Funeral Ceremony in Awramba}

In rural Amhara societies, funeral ceremonies are attended by a lot of people with impressive crying. Contrary to this custom, in Awramba community, funerals are attended only by some people for a very short period (a few hours). These funeral ceremonies correspond to the social and cultural system of Awramba, whose members do not believe in a life after death (Abebew, 2007, p. 63; Informants: Enanäy and Beretukan)

In the community every person shares the sadness or the happiness of any other individual. The community tries to fulfill the needs of a person in his life time as much as possible. If someone is ill, the community attempts to find ways to make him/her regain health. In this way, the community lives a guilt free life. This is what the community wishes for. But if all have been done to nurse back to health a sick person, and there are no more possibilities of healing him/her and the person dies, they believe, as "there is life coming into this world by birth, there is also a disappearance from it by death". This is considered a natural phenomenon (Ibid; Solomon, 2005, pp. 67-68).

However, when it occurs it is strange to them. If someone dies, it is beyond the capability of human beings to bring him/her back to life, so people may burst into tears. But there were not be any extreme grief. The informants express that Sadness cannot bring the dead back to life. If it had been possible to bring the dead back to life by extreme mourning, they would have gathered all the people and mourned (Informants: Zumra, Enanäy, Beretukan Ťähayi and Dämäqä; Awramba Mahebäräsäb, 2013, p. 17).

In the community, the funeral ceremony consists only of a few members performing the burial procedure. Some members of the community will stay with the family of the dead to help them forgot their sadness. After the burial ceremony has been completed, the family of the dead will go with other people to work. This is to make them forgot their grief. With this, the mourning ceremony is finished. After that, people are not allowed to remind the mourners of their loss and worsen their grief. Unlike the surrounding societies, the members gathered together 
during the funeral ceremony don't contribute any money, and the family of the deceased has no need to spend any money to feed the gathered mourners. If a person comes from a faraway place to attend the ceremony, the community will provide for him/her/. Hence, the family of the dead will not suffer from this unexpected expense. If the family of the dead has money, it is used for the benefit of children of the deceased. If they do not have enough money, the entire community will collectively take care of the children and the family of the departed (Ibid; Informants: Zumra, Enanäy and Beretukan).

\section{Old Age Protection in Awramba}

In Ethiopian society, the less fortunate and the old do not have anyone to take care of them. They may not even have anything to eat or anywhere to live. But the young and the stronger ones have a good time and don't have time to look after the less fortunate ones. The Awramba community believes that people always come first, and wealth comes second. Wealth, which is obtained through work, is necessary to feed people. When material possessions are utilized many times, they become useless, and they will be thrown away. When human beings age and are unable to work, they should not be thrown like material goods. The community believes that by saying:

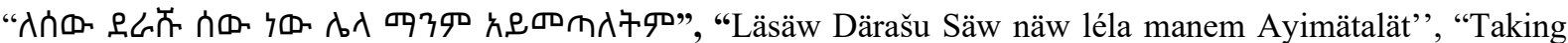
care of humans is the responsibility of humans themselves. No one else is going to do that". Therefore, the community guarantees support for those who are unable to work due to old age or health problems. The beneficiaries of this funding are identified by the Problem Identifying committee. After identifying the individuals who have harsh problems, the committee reports to the weekly development committee. The weekly development committee decides how much it can offer and will provide it (Fogära District Office, 2001 E.C. p. 16; Informants: Enanäy, Beretukan and Zumra).

The boundary between middle age and old age cannot be defined exactly because it does not have the same meaning in all societies. In Awramba community old age is defined by their own and the definition is based on capacity to perform any activity rather than any age and other related factors. This means if the person in the community is unable to perform any activities on the age of 40 or 50 and above, he/she may be considered as old (Ibid). In Awramba community old people live in the place prepared for them. There are 14 beds in the place which prepared for them and there are nine 9 old peoples who get protection from the community (Ibid).

Helping those who are unable to work due to ageing and health problems is one of Zumra's principles that he thought of at the age of four. He has put this principle into practice since he was only 13 years old. After he established the Awramba community he also continued helping needy people by farming their land and contributing cash until 1993 (Awramba Mahebäräsäb, 2013, p. 7).

But after the community returned to their original lands, following a period of forced exile, it was not possible to help needy people through farming because of shortage of farmland. As a result, the community tried to find other income generating activities. The income generating activity that the community found was spinning cotton and weaving. To do this, there was a need of money to buy cotton. To solve this problem each member of the community contributed one Ethiopian Birr in 1993. After the money was collected, they chose every Tuesday as a day to do spinning, weaving and other activities. Until today, every Tuesday members of the community participate in spinning, weaving, collecting fire wood and building shelter for needy people (Ibid; Informants: Enanäy and Beretukan).

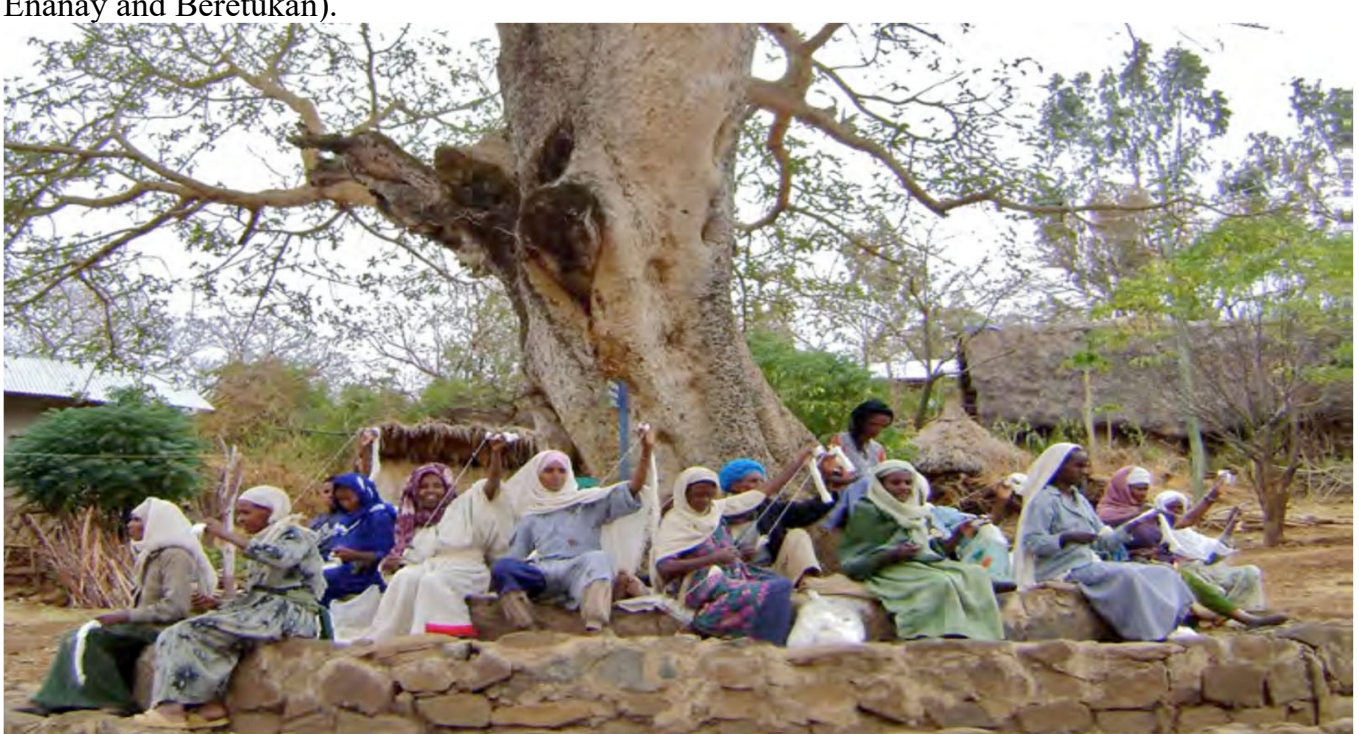

Figure: 3. Members of the Community spinning for 'LäwägänDäraš' program

Source: The Awramba community information center, 2018 
The money generated from this activity goes to a fund called 'Läwägän Däraš' 'arrive for needy', 'a fund that used for needy'. This fund is meant to support people who are unable to work; to provide treatment for sick people who have no money; to provide educational materials for orphaned children; and sometimes to support people living outside the community who are facing serious problems. 'Läwägän Däraš' also helps those who have no house due to lack of money, and those whose house is destroyed due to certain circumstances. It mainly helps the community members and people outside of the community who are facing harsh problems (Ibid; Informants: Enanäy, Beretukan and Zumra).

If the capital of 'Läwägän Däraš' increases, the idea is that it would support people in need anywhere. But for now, Läwägän Däraš is only sufficient to support a few people who are facing harsh problems. However, the vision for the fund is very wide. The goal is that the fund would support anyone in need throughout the world (like a charity). In addition to the fund raised by the community, the entrance fee collected from visitors is also added to 'Läwägän Däraš'. The purpose of the fund is to reach those who are facing harsh problems and to give them financial support (Ibid).

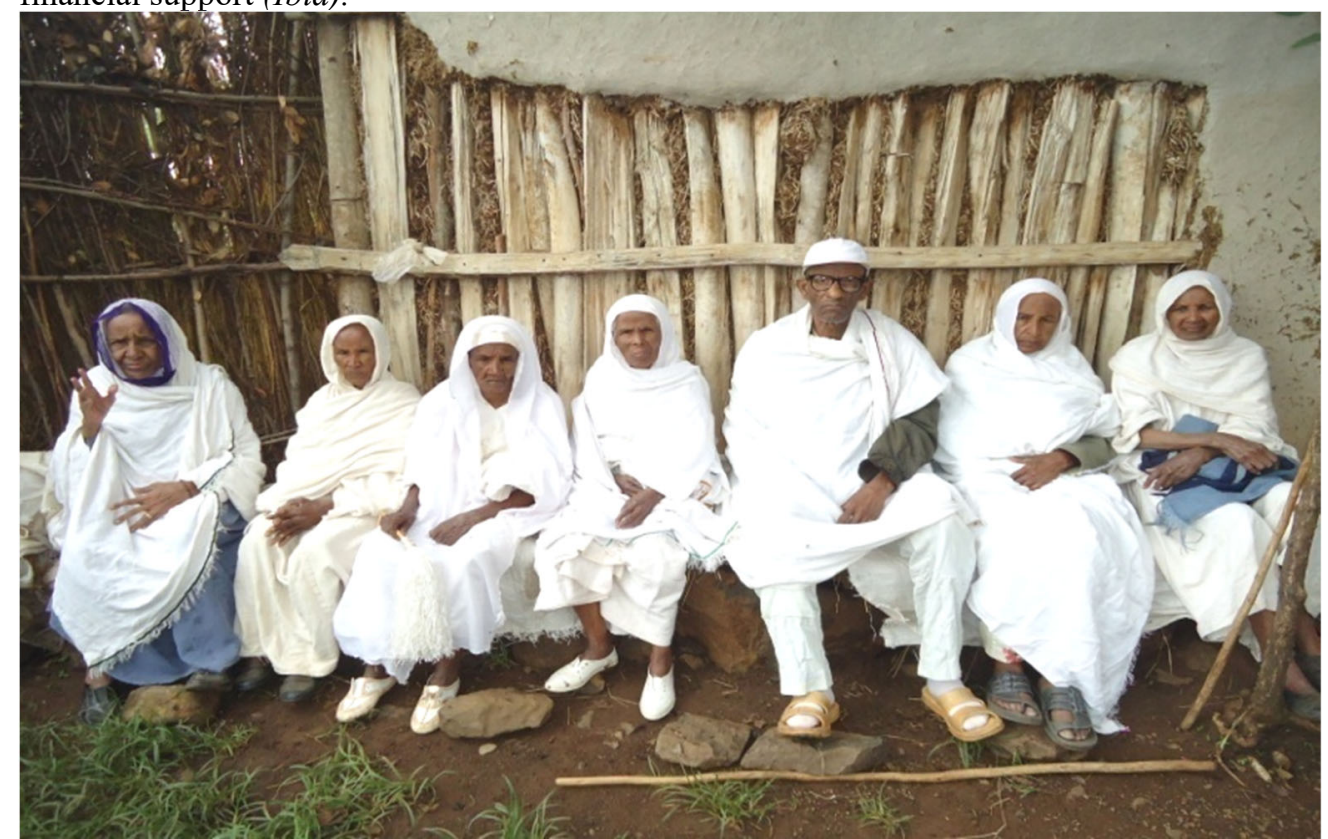

Figure: 4 . The elderly who are being cared for by the community

Source: Photo by Researcher

The community has its own committee which is responsible for taking care of elderly people. The committee uses funds collected from 'Läwägän Däraš' to provide food, clothing, and shelter for the elderly. They are provided with meals at regular intervals throughout the day. Their residence is cleaned every day. They take a bath every three days, and their clothes are washed every week. Consequently, they can enjoy the remainder of their life in comfort (Ibid).

In addition to taking care of elderly and sick people, the community members take care of orphans too. Like other children in the community, orphaned children are sent to school and are provided with educational materials. After they reach the age of 18 , they have the right to decide how to make a living. If they wish to live within the community, they are welcome to stay with the community. If they wish to leave the community and make their own living outside, they may do so. The community doesn't force them to stay only because they were brought up here. They are given the option to make their own choices (Solomon, 2005, p. 57 and 59; Informants: Zumra, Enanäy, and Beretukan).

\section{House building Style}

The houses of Awramba are built by mud with a flat corrugated iron roof. They are equipped with a stove and similar furniture in all houses, and often with a private weaving machine. The stove is a closed model specific to the village, designed by Zumra in 1979. It is raised off the ground to prevent young children from being burnt accidentally and has an outlet which sends away the smoke (this is not always the case in Ethiopia) (Said, 2008, p. 89; Informants: Enanäy, Beretukan, Ťähayi, Sänädu and Dämäqä).

The smokestack has a bend in it, on which water can be boiled, and which also enables it to be cleaned. Energy consumption for cooking is half as high as elsewhere according to the report by a German cooperation. Each house is also equipped with a kitchen dresser made of wood and mud. Each household has a Turkish design toilet on an open drain. These toilets are grouped together, and are located 50-100 meters outside the village. 
Houses and furniture are built from the same material as in every Ethiopian village (Ibid; Informants: Enanäy, Beretukan, Ťähayi and Dämäqä).

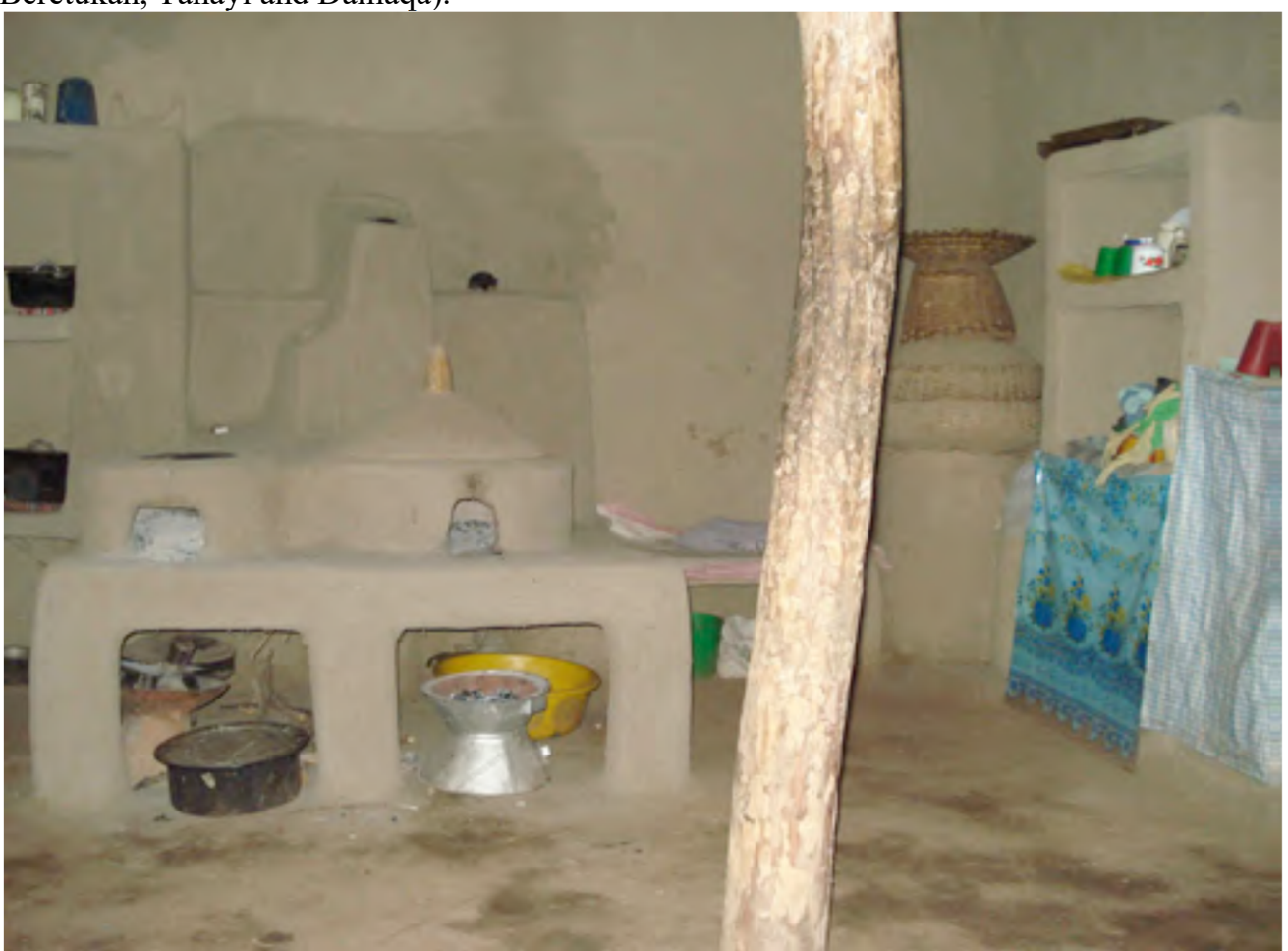

Figure: 5. Stove of Awramba in the kitchen

Source: Photo by Researcher

The difference is that they are built attractively, while bearing energy saving in mind, and also the need for furniture which can be made of the same mud, not limiting the design to just the basic roof and walls. The village has some waste containers, which is most unusual in the rural part of Ethiopia, in which the rubbish is burnt outside the village. All homes have electricity, and water is available at four taps installed by the condition: it is free at the old manual pump, and has to be paid for at the taps connected to a diesel pump. Power decrease Stoves are common to all houses in the community. The family houses and all their supplies belong to the families and are managed by them (Solomon, 2005, p. 52; Abebew, 2007, p. 44).

\section{Other Unique Characteristics of the Community}

The community has other different unique characteristics including sanitation; home keeping etc. The education system of the community also differs from the surrounding society, in addition to modern education, in that they also learn their own local education of weaving and technical experience. The children are educated in kindergarten schools the behavior and the experience of the community (Informants: Enanäy, Beretukan, Tähayi, Sänädu and Dämäqä).

They also produce all furniture's by themselves. Internal parts of the houses are made so as to be easily partitioned and suitable for cleaning and decoration. Their beds, stools, shelves, and the like are made up of mud, bricks and wood. Their kitchens are also modern. Speaking of their kitchen, wäyzäro Enanäy Kiberät said that is saves fuel and protects their skin from being exposed to the fire and heat (Ibid; Informants: Nuru and Tadässä).

\section{Influences of Awramba community}

Culture often motivates a given society's thinking, speaking, feeling and experience. In order to analyze cultural influence, it is essential to classify culture in to two: material and non-material. Any influence up on the culture may be manifested by the changes in material culture or non-material culture or both. So it is better to see the influences separately (Adelakun, 1990, p. 7).

\section{Influences in material}

The Material culture of Awramba influenced many neighboring societies in many aspects. Material culture consists of all material objects that distinguish a group of people such as their art, building, weapon, machine, hair style, and clothing. It is a physical or technological aspect of our daily life including food items, houses, pots, factories and raw materials (Richard, 2005, P. 65).

Among these are: 
Housing style: The community of Awramba is not as such different from the housing patterns of the surrounding society. The different is related to who build the homes. For the community of Awramba they build their homes by themselves. They cannot use any designer or engineer; rather they do all designing or construction by themselves. But the surrounding societies consent to some activities to engineer and others designers when we compare with Awramba (Biniam, 2009, p. 27; Informants: Enanäy and Beretukan).

Clothing style: The clothing style of the members of the Awramba community is mainly different from others. The women of the village rarely wear traditional clothes, unlike women of the neighboring villages. It shows without doubt a refusal to accept the traditional customs, as well as the distance of community members from the customs of their neighbors. Most of the time members of the community use their products which were produced by them with their light textile industries. Especially, the leader of the community, Zumra, mostly uses and motivates the members to use cloth that is produced by the community. Females of the community use clothes that are designed by the modern style but the surrounding society's clothing style are very traditional when we related with Awramba community. Clothing style of females of the surrounding society is long dress that is made from cotton by local weavers and they call it "gorada" (Ibid, pp. 28-29).

\section{Influence in non-Material Culture}

Non material cultures refer to non-physical phenomena, process and ideas, thinking including beliefs, values and other assumptions about the world and doing its common patterns of behavior, including language (Richard, P. 65; M. James, 1996, p.35).

The community of Awramba influences the surrounding society by its non-material culture like attitude toward the right of women, attitude towards division of labor, attitude on religion and marriage. When we compare the influence of community' on material and non-material culture of surrounding society, non-material culture of the community is not influencing the non-material culture of the surrounding society as a whole. It is mainly because the surrounding communities consider the Awramba practices out of the ordinary behavior that the means and/or gained some thing is negative and surrounding society consider the community as ground breaking (Biniam, 2009 p. 30; Informants: Enanäy, Beretukan and Zumra).

In general, the surrounding communities are society now changing their negative attitudes towards the cultural elements of Awramba especially on their old protection and work ethics. But they still maintained a negative attitude towards the religion and marriage practices of the community. Awramba community is considered different from the rest of the society by their innovative way of housekeeping. They designed their cooking area, which make their houses smoke free as a result reduced the energy consumption as compared to the rest of the society (Informants: Enanäy, Beretukan and Zumra, Ato Bamelak Täsäma and Käbädä Aseräs). Nowadays, people from all around the world make a long journey to this small village to hear their history and learn about their way of life. After returning to their homes, visitors tell to their families, friends and colleagues about the community. Thus, the number of visitors to Awramba has increased over time. Those visitors include governmental administrators, famous individuals, non- governmental organizations, journalists, and foreign tourists. For instance, from September 11, 2001 to September 10, 2012, 51,469 individuals visited Awramba (Getu, 2010, p. 17).

\section{Conclusion}

The foundation of Awramba community can be traced back to1972 when the community was established. This community was established by philosophy of one visionary man, called Zumra Nuru Muhammad and he has unique vision and exceptional personality. He shared his five basic principles with the community as to how to put these principles into practice in a way that would be relevant for their lives. The principles are: respecting the right to the equality of women, respecting children's rights, helping people who are unable to work due to old age and health problems like, avoiding bad speech and bad deeds, such as theft, dishonest, insulting, cursing, quarrelling, killing, conflict, etc., instead improving practices of cooperation, peace, love, and good deeds in general and accepting all human beings as brothers and sisters, regardless of their differences.

The community has their own system of commonality, social organization, administration system, traditional conflict management system, economic activities and other social relationships. The community of Awramba shares a strong culture and ideals with each other, which differentiate them from the Amhara society and their neighboring villages, and above all they shared common values. Among those unique characteristics that make them different from the surrounding society, and also most part of Ethiopia, are their work ethics, equality especially gender equality, division of labor, religion, marriage and divorce, old age protection, solidarity, funeral, house building design /style/and others. The Awramba community faced different challenges in different period. Even if Awramba has plans for friendly interaction with them, the majority of surrounding communities have failed to appreciate the good will. 


\section{References}

\section{Unpublished sources}

\section{Manuscripts}

Awramba Community Development Committee, "The Journey for Peace", unpublished document (this material is in possession Awramba community, 2013.

Awramba Mahebäräsäb Wuseţä Däneb Awuči Committee, "Yä Awramba Mahebäräsäb Mätädadäriya Wuseţä Däneb”, 2002.

Fogära District Office, Yä Awramba Hezeboč Tarik" (This material is in possession of Fogära Culture and Tourism Office) 2001 E.C.

II. Papers and Theses

Abebaw Yirga, "The Cross-cultural Experience of the Awramba Children at Primary School: Implication for Multicultural Education, (Master thesis, Ethiopian Language and Education, Addis Ababa University (AAU), 2007.

Amsalu Kindalem, "Indigenous Knowledge as a Live-hood Strategy in Awramba Community", BA thesis, Government Development Studies, Jimma University, 2009.

BiniamTilahun, "The Influence of Awramba Community Sub-Social Life Development on Surrounding Society", BA thesis, Sociology and Social Work, Jimma University, 2009.

Dereje Yilma, "The Awamba Community and their Concepts of Work Ethics viewed from Biblical Perspective", BA thesis, Theology, Mekane Yesus, 2013.

Eskinder Teferi, "The Role of Gondar Equality in Promoting peace and Development: The case of Awramba Community in Fogera Woreda of Amhara National State, Ethiopia", MA thesis, Peace and Security Studies, AAU, 2012

Getinet Meride, "A History of the Awramba Community, 1972-2012, South Gondar," MA thesis, History and Heritage Management, Jimma University, 2014.

Getu Demeke, "Rural Self-Administration: In case of Awramba Community," Mphil thesis, Philosophy, Norwegian University, 2010.

Merhatsidk Abebayehu, "The Wisdom of Mediating Family Disputes in the Awramba Community: Is it sustainable and Worth Replicating" (Master thesis, Peace and Security Studies, A AU, 2009.

Said Mohammad, "The Working Traditions and their Contribution to Rural Development in Awramba Community, North Amhara Region, Ethiopia,', MSc thesis, Cooperative Marketing, Mekelle University, 2008.

Solomon Atnafu, "Social Transformation among the Awramba community (North-Western Ethiopia, Amhara region): Change in Gender Roles and Values", Master thesis, Sociology and Social Anthropology, AAU, 2005

\section{Published Sources}

\section{Articles and Journals}

Dereje Kifle, "Gender Role in Agriculture Productivity in Some Parts of Ethiopia", International Journal of Research in Applied, Natural and Social Sciences (IJRANSS), Vol. 1, No. 2, Haramaya University, Dire Dawa, 2013.

Guday Emirie and Eskindir Teferi, "Gender relations in Access to and control over Resources in Awramba Community of Amhara Region, Ethiopia”, Ethiopian Journal of the Social Science and Humanity, Vol. 9 No. 2, Addis Ababa, 2013

\section{Books and Magazines}

Bahru Zewde, A History of Modern Ethiopia 1855-1991, Second Edition (London, Athens, Addis Ababa), 1991.

Debub Gondar Zone Information Bureau, Hayagnaw Kefla Zemen Yebahel Lewt Meseret Ya Awramba Mahebereseb, Bahir Dar, 2000 E.C /2008/.

Geremew Tadele, Awrambawoch, Addis Zemen Newspaper, Addis Ababa, Megabit, 7, 1994 E.C.

Henslin, M. James, Sociology, Dawn to Earth Approach, $4^{\text {th }}$ ed. South Illinois University, Canada, 1996.

Mohammed Mussa, Empowerment Effective of Ethiopian Citizenship, Addis Ababa, 1996.

O. A., Adelakun, The Concept of Culture, Jos, Imico Publisher Company, 1990.

Oslow, H. David, Marriage and Family, $3^{\text {rd }}$ Edition, Mayfield Publisher Company, London, 2000.

Qum Nagar Magazine, Vol. 9, №. 101, Addis Ababa, 2010.

Vol. 6, No. 103, Addis Ababa, 2012.

T. Schaefer, Richard, Introduction to Sociology, $8^{\text {th }}$ ed., Philip A butcher publisher, USA, 2005. 
List of Informants:

\begin{tabular}{|c|c|c|c|c|c|}
\hline \multirow[t]{2}{*}{ No } & \multirow[t]{2}{*}{ Name } & \multirow[t]{2}{*}{ Age } & \multicolumn{2}{|l|}{ Interview } & \multirow[t]{2}{*}{ Remark } \\
\hline & & & Date & Place & \\
\hline 1 & $\begin{array}{l}\text { Bamelak } \\
\text { Täsäma } \\
\text { (Ato) }\end{array}$ & 70 & February, 26, 2018 & $>>$ & $\begin{array}{l}\text { He is the neighbor of the community and } \\
\text { now he is the elder and honor person. }\end{array}$ \\
\hline 2 & $\begin{array}{l}\text { Birtukan } \\
\text { Kiberät } \\
\text { (Wayzaro) }\end{array}$ & 38 & January 29, 2018 & $>>$ & $\begin{array}{l}\text { She is guider of visitors whom came from } \\
\text { different areas and she explains about the } \\
\text { destination of the community's unique } \\
\text { culture and values. }\end{array}$ \\
\hline 3 & $\begin{array}{l}\text { Dämäqä } \\
\text { Ahmad } \\
\text { (Ato) }\end{array}$ & 27 & February 16, 2018 & $\begin{array}{l}\text { Awramba } \\
\text { Kebele }\end{array}$ & $\begin{array}{l}\text { He is the member of the community and } \\
\text { shopkeeper man. }\end{array}$ \\
\hline 4 & $\begin{array}{l}\text { Edeyä Ahmed } \\
\text { (Wayzaro) }\end{array}$ & 39 & February 26, 2018 & $\gg$ & $\begin{array}{l}\text { She is member of the community and now } \\
\text { she does make in weaving activities. }\end{array}$ \\
\hline 5 & $\begin{array}{l}\text { Enanäy Kiberät } \\
\text { (Wayzaro) }\end{array}$ & 38 & February 29, 2018 & $>>$ & $\begin{array}{l}\text { She is the wife of Zumra Nuru the co- } \\
\text { founder and chair man of the community. } \\
\text { She had a higher position in the } \\
\text { community next to her husband. }\end{array}$ \\
\hline 6 & $\begin{array}{l}\text { Käbbäddä } \\
\text { Aseräs } \\
\text { (Ato) }\end{array}$ & 65 & January 16, 2018 & Wajji & $\begin{array}{l}\text { He is of the neighboring of the Awramba } \\
\text { community and farmer. }\end{array}$ \\
\hline 7 & $\begin{array}{l}\text { Mälekamu } \\
\text { Alämu (Ato) }\end{array}$ & 42 & January 16, 2018 & $>>$ & $\begin{array}{l}\text { He is member of the community and the } \\
\text { operators of wireless telephone of the } \\
\text { communities. }\end{array}$ \\
\hline 8 & $\begin{array}{l}\text { Märeša } \\
\text { Gäbäyähu } \\
\text { (Ato) }\end{array}$ & 48 & January, 7, 2018 & $>>$ & $\begin{array}{l}\text { He is the member of the community and } \\
\text { now he is one of a committee of }\end{array}$ \\
\hline 9 & $\begin{array}{l}\text { Nuru Bälay } \\
\text { (Ato) }\end{array}$ & 38 & January 29, 2018 & $>>$ & $\begin{array}{l}\text { He is the member community and he is } \\
\text { now one of committee of complaint and } \\
\text { organized different activities. }\end{array}$ \\
\hline 10 & $\begin{array}{l}\text { Sänädu Yiberé } \\
\text { (Ato) }\end{array}$ & 27 & February 16, 2018 & Alember & $\begin{array}{l}\mathrm{He} \text { is the member of community. } \mathrm{He} \\
\text { works at shop. }\end{array}$ \\
\hline 11 & $\begin{array}{l}\text { Țähay Dämäqä } \\
\text { (Wayizäro) }\end{array}$ & 35 & February 29, 2018 & $>>$ & $\begin{array}{l}\text { She is member of the community and } \\
\text { casher of the union of the community. }\end{array}$ \\
\hline 12 & $\begin{array}{l}\text { Zumra Nuru } \\
\text { (Ato) }\end{array}$ & 68 & $\begin{array}{l}\text { February, } 16 \quad 2019 \\
\text { and January19,2018 }\end{array}$ & $\gg$ & $\begin{array}{l}\text { He is the founder and still chairman of the } \\
\text { community. }\end{array}$ \\
\hline
\end{tabular}

